\title{
Multi-OMICS and Molecular Biology Perspective in Buffalo Genome
}

\author{
Suranjana Sikdar ${ }^{1,6}$, Tuhin Das ${ }^{1}$, Emran Hossain Sajib², Kazi Mahbub Ur Rahman ${ }^{3}$, \\ AMAM Zonaed Siddiki ${ }^{4,6, *}$ and Md Bashir Uddin ${ }^{5,6, *}$
}

\author{
${ }^{1}$ Department of Microbiology, University of Chittagong, Chattogram-4331, Bangladesh \\ ${ }^{2}$ Faculty of Biotechnology \& Genetic Engineering, Sylhet Agricultural University, Sylhet-3100, Bangladesh \\ ${ }^{3}$ Senior Assistant Secretary, Government of the People's Republic of Bangladesh \\ ${ }^{4}$ Department of Pathology and Parasitology, Chattogram Veterinary and Animal Sciences University, \\ Chattogram-4202, Bangladesh \\ ${ }^{5}$ Department of Medicine, Sylhet Agricultural University, Sylhet-3100, Bangladesh \\ ${ }^{6}$ Genomic Research Group, NextGen Informatics Ltd., Chattogram-4202, Bangladesh
}

\begin{abstract}
The bovine species buffalo was domesticated from its wild strain Bubalus arnee and is widely used livestock in southern Asia. There are two distinct types of Buffalo- the swamp buffalo (B. bubalis kerebau) and the river buffalo ( $B$. bubalis bubalis), which diverged from the wild Asian water buffalo and then evolved in separate geographical regions. Several research studies performed on buffalo, like- characterization of trait-specific Single Nucleotide Polymorphism (SNP), genetic and phenotypic diversity, gene prediction and function annotation, mapping of the draft genome, have helped our understanding of the buffalo genome. Some advanced discovery as identification of Single Nucleotide Variant (SNVs), Simple Sequence Repeats (SSR) marker and their association with various phenotypic traits, MicroRNA's expression profiling, whole-genome sequencing, etc. have also enabled us to track the chromosomal evolution, physiological processes, and gene expression of buffalo. Proper enhancement of these traits can lead us to apply multiomics-based tools for better animal health and production. Recent advancement in genomic research on buffalo is being accelerated with the association of modern tools like- Genome-Wide Association Study (GWAS), genotyping by sequencing, epigenomic screening, microRNA's expression profiling, microarray technology, and whole-genome sequencing. All these tools bear great significance in breed up-gradation, identification of the phylogenetic relationship between species in proteome and genomic level, study gene expression level, diagnose diseases or developmental stages, phenotypic diversity, etc. All this knowledge paved the way for better optimization of production efficiency, product quality, and resistance to certain health hazards.
\end{abstract}

Keywords: Buffalo, Genomics, Proteomics, Whole genome sequencing, GWAS, SNP, Microarray, Conservation, Breed up-gradation, Gene expression.

\section{INTRODUCTION}

Buffalo is a multipurpose indispensable ruminant livestock possessing social, cultural, and economic importance [1-3]. Buffaloes, members of bovine animals, can be classified into two main species: African wild buffaloes (Syncerus caffer) and Asian buffaloes (Bubalus bubalis) $[4,5]$. Dairy buffalo production is very familiar in Asia, especially in South Asian countries, for instance- Bangladesh, India, Pakistan, Afghanistan, etc. Buffalo contributes to the economy enormously as a source of food production. It is a great source of meat, milk, and milk products like ghee, butter, cheese, yogurt, ice cream [1]. Buffalo milk is more nutritious than that of other cattle. As it utilizes coarse feed more efficiently than cattle, it possesses more disease resistance power and produces more solid in milk [6].

Moreover, it contributes to crop productivity by providing draught power and transportation, dung as

*Address correspondence to these authors at the Genomic Research Group, NextGen Informatics Ltd., Chattogram-4202, Bangladesh;

E-mail: zsiddiki@gmail.com (ZS), bashir.vetmed@sau.ac.bd (MBU) fuel and organic fertilizer, livelihoods and nutrition to poor households, and hiding as raw material for the leather industry and many others [7-9]. Water buffalo, also known as the river buffalo (Bubalus bubalis), is the second essential one having a colossal role in milk production, drought, and transportation [4, 10, 11]. It is often called a living tractor for its great role in plowing.

The economy of Bangladesh is dependent upon agriculture and livestock. Most of the people of villages earn their livelihood through farming, livestock rearing, and selling the products produced from livestock. Buffalo is the next to the cattle that have been a long time contributing to smallholder farmers vis-à-vis the national economy. These are mainly managed in the household subsistence of smallholder farmers and extensive bathan farming in the saline coastal region in Bangladesh [6]. Buffalo can play an indispensable role in the context of Bangladesh regarding agriculture, livestock, food, and nutrition. However, it is a matter of regret that, in comparison with other Asian countries, its number is quite low in Bangladesh. The total buffalo population in Bangladesh is 1.457 million, having $40 \%$ 
of this number in the coastal region [12, 13]. Buffalo can benefit us through dairy products, plowing, rare drought season, and a great source of transportation. In spite of so many advantages, buffalo production remains a neglected part of Bangladesh. Although buffalo numbers have increased during the last ten years, milk production has not yet increased to the desired level due to negligence. Buffalo milk is now becoming popular gradually among consumers due to its high-fat content and flavor, which vastly increases the demand for buffalo. However, because of less potential surveillance, buffalo is not producing enough milk and suffering from various diseases. This signifies the necessity of research on buffalo assessing its genetic resources, distributions, physical and inheritance characteristics, production and reproduction performances, strategies for buffalo development, etc. Broadening knowledge about buffalo and its imposition to a significant era can enhance its milk production and other possible factors that can be very profitable for Bangladesh and its economy.

\section{BACKGROUND OF BUFFALO RESEARCH IN THE ASIAN SUBCONTINENT}

Buffalo production and its rearing are quite high in Asian countries. In the Asian region, most buffaloes $(79.74 \%)$ are from South Asian countries [14]. India, Bangladesh, Pakistan, Afghanistan are the prime amongst them. According to FAO (2014), the total population of buffalo is the highest in India (56.61\%), followed by Pakistan (17.78\%), Nepal (2.66\%), Bangladesh $(0.746 \%)$, and Sri Lanka (0.16\%) [9]. During the last few decades, buffalo production has been raised, which was almost 20 million and $84.91 \%$ in Asia [15]. Despite the enhancement in number, research in buffalo has been neglected so far, and it is way too less compared to other cattle [16].

In India, research work was done with a sample size of 134 to assess the inter-relationship between sexual behavior, peripheral hormones (kisspeptin and testosterone), and seminal variables of Murrah buffalo bulls. Kisspeptin is responsible for reproductive functions [17]. Kisspeptin activates gonadotropinreleasing hormone $(\mathrm{GnRH})$ neurons resulting in $\mathrm{GnRH}$ release. The $\mathrm{GnRH}$, in turn, stimulates the release of the gonadotropins, which helps in the stimulation of male gonads [18]. As a result, they demonstrated that $13,37,40,6$, and $4 \%$ of Murrah buffalo bulls had a reaction time of $<30,31-60,61-180,181-300$, and $>300$ seconds, respectively. They also found that 4,85 , and $10 \%$ of buffalo bulls were active, sexually aggressive, and dull, respectively, during semen collection. Serum kisspeptin and testosterone possess negative effects on reaction time, sexual aggressiveness, penile erection, and positive effect in spermatogenesis [19]. In another study, the relationship of blood metabolic changes and average daily gain with feed conversion efficiency were assessed in Murrah Heifers (Murrah buffalo) through a machine learning approach [20]. Another group of researchers conducted research using antioxidant micronutrient supplementation in Murrah buffalo, enhancing udder health and milk production [21]. Semen parameter and fertility potency were performed using cloned water buffalo (Bubalus bubalis) in a study [22]. Moreover, various researches were done in India about the effect of progesterone on water buffalo, identification and characterization of traitspecific SNPs using ddRAD sequencing in water buffalo, nanotechnological application in buffalo, etc. [23-25]. The Central Research Institute of India focuses on comprehensive research on buffalo breeding and production [26].

In Pakistan, a study showed the genetic and phenotypic diversity in buffalo, whereas in Afghanistan, an epidemiological study was performed with foot-andmouth disease buffalo [27, 28]. In Bangladesh, the Coronavirus genome sequence was performed from water buffalo [29]. Draft genome of Asian water buffalo has been discovered through genome sequencing and assembly; later, gene prediction and function annotation have been made [30]. Therefore, research in Bangladesh, Pakistan, Afghanistan, Sri Lanka, and other low economic Asian countries are very poor. As a result, though the number of buffaloes is increasing, it could not contribute enough to the economy due to certain constraints.

\section{BUFFALO MOLECULAR RESEARCH AROUND THE WORLD}

Very few data are available regarding buffalo research using molecular techniques. Recently, whole genome sequencing (WGS) analysis of water buffalo has been done by a group of scientists. They have sequenced 73 buffaloes from six different regions of India- Banni, Bhadawari, Jaffarabadi, Murrah, Pandharpuri, and Surti. They identified a final set of $26,247,559$ biallelic SNVs and amongst those, 25,513,085 were autosomal [31]. In China, based on their mitochondrial DNA (mtDNA) Control Region (Dloop) diversity, a phylogenetic assay was performed to assess the domestic history of swamp buffalo [32]. Genetic diversity and distance among Chinese Buffalo based on microsatellite data have also been performed 
[33]. Transcriptomic analysis of swamp buffalo results in 54,109,173 raw reads after Illumina paired-end sequencing. After the de novo assembly, they found 86,017 unigenes, with an average length of $972.41 \mathrm{bp}$, an N50 of 1,505 bp, and an average GC content of $49.92 \%$. They basically used Illumina RNAseq technology for transcriptome analysis and SSR marker discovery in the swamp buffalo [34]. Based on a comparative study, comparisons among swamp and river buffalo have been made by sequencing mitochondrial $\mathrm{D}$-loop region and cytochrome $\mathrm{b}$ gene. This study provides important information about the genetic diversity among two different species [35] other than China and India. Other than that, there is a lack of enough research associated with the molecular level in buffalo.

\section{GENOMIC DATA AVAILABLE TILL NOW}

A plethora of genomic data of buffalo has been deposited to the NCBI database (https://www.ncbi.nlm.nih.gov/search/all/?term=buffalo) to date. A total of $1,921,573$ nucleotide sequences have been identified. Amongst those, 1,028,950 are for water buffalo, 971 for swamp buffalo, and 1,416 for African buffalo. Alongside, 4,942 SRA data with 44 taxonomic classifications is present in the NCBI database. Twenty-six mitochondrial genome sequencing of water buffalo can be found in GenBank.

Moreover, 34,831 genes, 1,005,613 proteins, and 51,970 identical proteins are also deposited in the database. More genomic data have been accumulated about water buffalo, including next-generation sequencing, compared to other buffalo species. According to Anand Agricultural University, a total of $1,498,523$ buffalo sequences has been performed, and their data had been submitted to GenBank (ACZF020000001-ACZF021498523), which are ranged from $92 \mathrm{bp}$ to $4,726 \mathrm{bp}$ in size. With the collaboration of the University of Florida and Washington State University, Illumina GAllx technology was used to produce approximately $40 \mathrm{~GB}$ of sequences for water buffalo [36]. Advancement in genomics and proteomics of buffaloes until the recent year is presented in Figure 1.

FUTURE POSSIBLE ASPECTS IN BUFFALO RESEARCH AT GENOMICS AND PROTEOMICS LEVEL

This review article emphasizes buffalo's genomics and proteomics resources that would provide important information about the buffalo breed's up-gradation, conservation, milk production, and disease resistance. The future research prospect on buffalo species and potential outcomes are thematically presented in Figure 2.

\section{MOLECULAR CHARACTERIZATION}

The last few decades were the golden time of molecular genetics, from the innovation of nextgeneration genome sequencing until the implication of those techniques in the molecular characterization of animal beings. That being associated with quantitative genetics, proteomics, and metabolomics has become a powerful tool for genetic polymorphism studies.

With the advent of modern techniques, likemorphologic character associated biochemical marker identification, the discovery of restriction enzymes and polymerase chain reaction, amplification, and detailed study of desired gene fragments has been quite feasible. These molecular markers can be targeted for the characterization of buffalo species with different objectives. Hence, the study of productive character associated genes attended reproduction and even tracing the buffalo species from which the product originated can be the next phase of buffalo research from the molecular characterization perspective. An example of such a study involving Random Amplified Polymorphic DNA (RAPD) was conducted by Albuquerque and colleagues, who characterized two genetic groups of buffalo- Carabo and Baio, and verified their genetic alignment [37]. Based on their findings, it can be concluded that this RAPD markerassociated technique can be implemented in our country to quantify the genetic variability of different groups of buffaloes in Bangladesh as well as from other neighboring countries from this subcontinent.

Meignanalakshmi and Nainar conducted a Polymerase Chain Reaction- Restriction Fragment Length Polymorphism (PCR-RFLP) analysis of betalactoglobulin gene followed by milk protein typing [38]. After digesting the PCR product with the Haelll enzyme, only a monomeric banding profile was observed. This result was also corroborated by the milk protein typing analysis showing no polymorphisms in the protein pattern. That experiment concluded that PCR amplification and RFLP analysis could be used as an important tool to investigate polymorphism at betalactoglobulin (b-LG) locus (the gene responsible for milk protein) directly at the DNA level. Another study showed that species-specific PCR and PCR-RFLP techniques could be used for the rapid identification and authentication of buffalo milk at the species level [39]. Therefore, this can be implemented for proper 


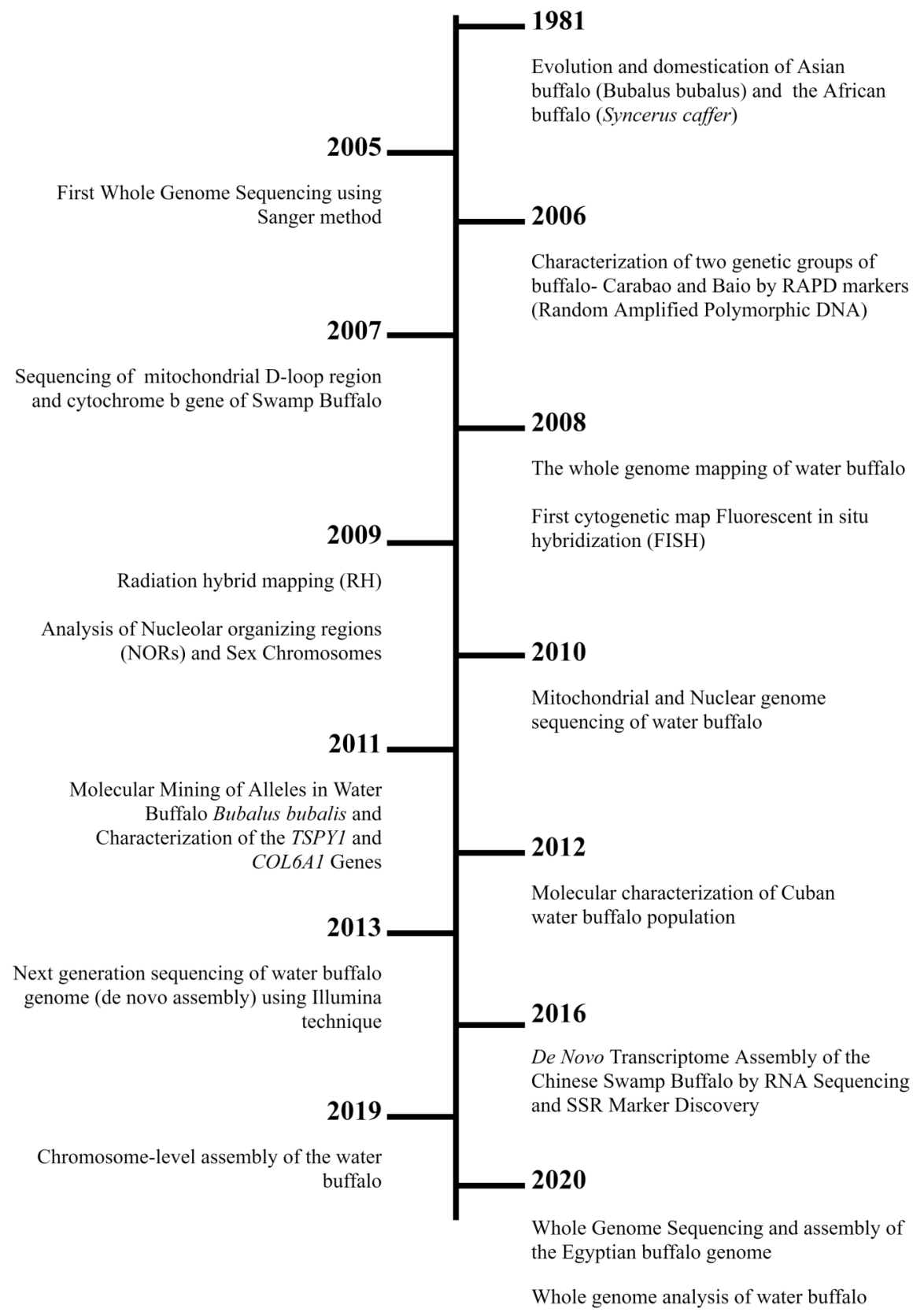

Figure 1: Schematic presentation of advancement in the field of genomics and proteomics of buffaloes.

tracing of buffalo milk in the Asian subcontinent too. Although a few microsatellite markers are available in buffalo, a study on river buffalo showed 498 as polymorphic among 571 cattle microsatellite markers [40]. This tremendous result indicates the effectiveness of cattle microsatellite markers on buffalo to study population genetics and complex traits.

Furthermore, the AFLP sequence analysis technique can be used to develop gene-specific genetic markers as well as to screen genes responsible for interesting traits. For instance, several AFLP markers were identified specifically for the calving interval $(\mathrm{Cl})$ of Thai swamp buffalo [41]. This trait is highly essential to select buffaloes with high fertility and thus differentiate from low fertile buffaloes. Thus, these biological markers can bear great significance in the future study of genetic diversity and breed upgradation.

In a study based on proteome analysis, it was found that the tenderness of buffalo meat largely depends on the kind of structural proteins [42]. The study revealed that meat from old buffalo possesses higher myoglobin redox stability and total protein extractability and the young buffalo meat had lower Warner-Bratzler Shear 


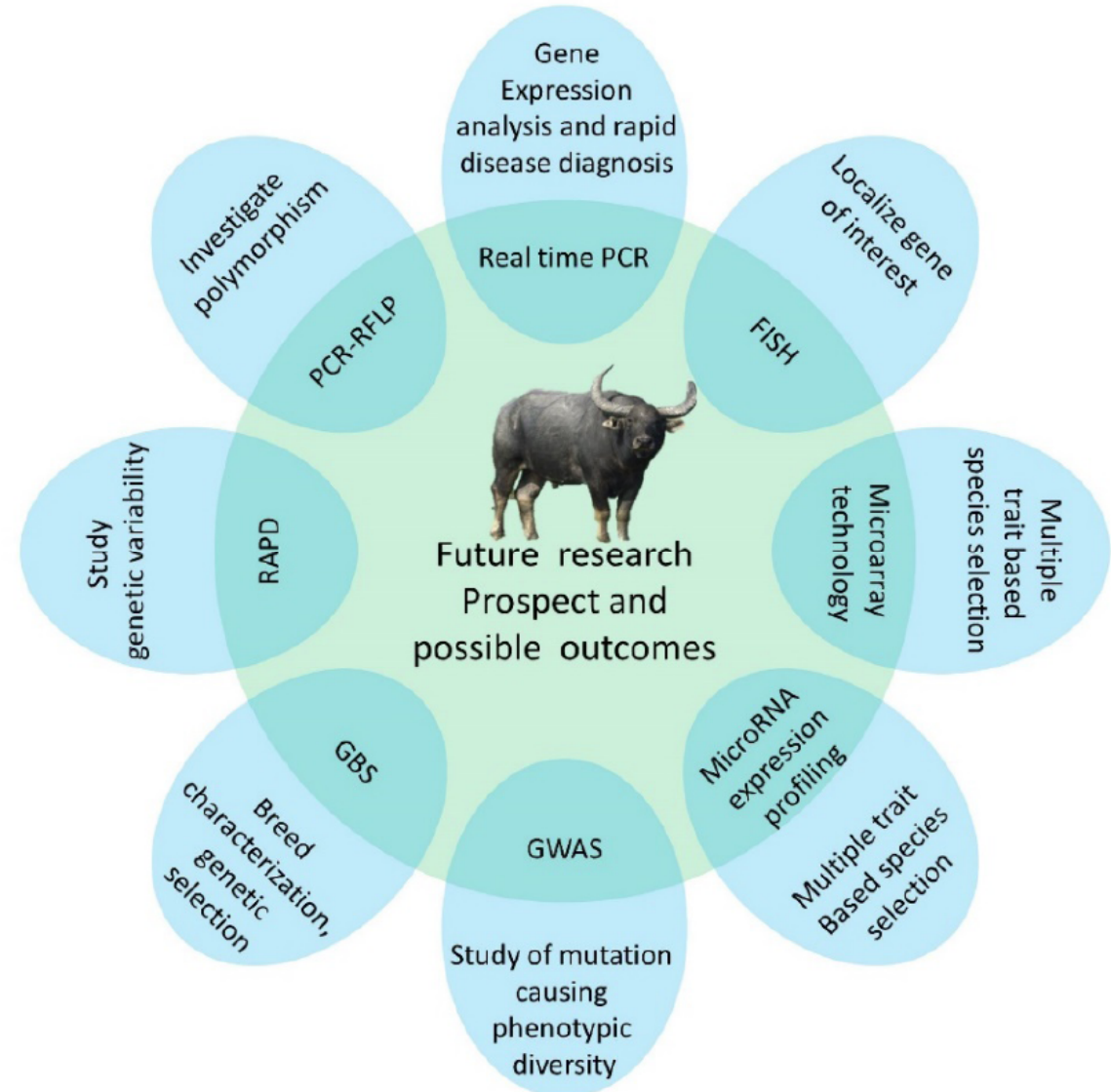

Figure 2: Future research prospects on buffalo species and potential outcomes.

Force (WBSF) and sarcomere length. It was also found that some specific proteins-complement $\mathrm{C} 1 \mathrm{q}$ subcomponent subunit $B$, uroplakin-1b, aspartate aminotransferase, myosin-a, glycogen phosphorylase, cytosolic carboxypeptidase 3 , and phosphatidylinositol transfer protein $\beta$ isoform are associated with the tenderness of buffalo meat in terms of their expression level. Hence, quantification of such protein biomarkers can help us distinguish between young and old buffalo meat, leading to optimization of buffalo meat processing, resulting in improved buffalo meat quality.

\section{CONSERVATION}

Aside from conventional sperm, oocytes, or embryo storage, it is now possible to store the DNA and embryonic stem cells to conserve endangered breeds. These techniques can be implemented to conserve the potential buffalo breeds for higher functionalities. The genomic DNA's presence under cryogenic condition technique can be followed to store the genetic material [43]. For this purpose, DNA bank strategy may be incorporated within and across different countries to store the DNA as it is more economical and feasible than previously practiced live-cell storage techniques.
As a long-term strategy, identifying target genes for nutrition value and quantity of milk and meat can be performed based on selective cloning or markerassisted selection.

Buffalo breeds on the brink of extinction have certain unique sets of genes that enabled them to subsist and adapt to adverse conditions. Such genetic combinations can be perpetuated through molecular characterization of those gene sets. Furthermore, these studies can lead to the maintenance of species that can resist unsuitable environments, emergent diseases and supplement the human population's nutritional needs.

\section{BREED UP-GRADATION}

In case of breed up-gradation, genetic polymorphism in the reproductive candidate genes was studied for their association with calving interval as a predictor of the reproduction efficiency of fertility status [44]. When the PCR product of the follicle-stimulating hormone receptor (FSHR) gene was analyzed, it showed three polymorphic patterns. The study concluded that insulin-like growth factor (IGF-1R) 
pattern 2 of signal transducer and activator of transcription 5 (STAT5A) gene locus are associated with high fertility, while pattern three was associated with low fertility. Such molecular information combined with phenotypic data could be used to develop a useful protocol for enhancing reproductive efficiency in buffaloes.

In another study, two-dimensional electrophoresis and matrix-assisted laser desorption/ionization time-offlight tandem mass spectrometry (MALDI-TOF/TOFMS) was applied to assay the proteins that are distinguishingly expressed in high- and low-motility sperm of buffalo [45]. The study had revealed dense outer fiber of sperm tails protein 2 (ODF2) and ATP synthase subunit alpha (ATP5A1) were downregulated, whereas succinyl-CoA synthetase subunit beta (SUCLG2) was upregulated in the low motility sperm. As sperm motility is directly related to the fertility of the species, identification and quantification of these proteins can successfully predict the reproductive efficiency of target species. These techniques, if applied, can help to breed for higher reproduction in buffalo selectively.

\section{CURRENT TOOLS AND TECHNIQUES AVAILABLE FOR GENOMIC STUDY OF BUFFALO}

\section{GWAS}

Genome-Wide Association Studies (GWAS) is a recent perspective of modern genetics that deals with the association of specific genetic variations with particular diseases. This method involves the genomewide search for certain genetic markers whose presence can be used to predict any diseases. Although it was first developed for humans, it also changed the approach towards livestock genetic study and is now used for detecting various genes responsible for phenotypic variations [46], susceptibility to diseases, and economically significant traits. GWAS involves a certain set of techniques used for genetic screening to locate the desired gene in the genome with a view to characterize and map the locus of the gene that affects the target trait of interest [47]. Identification of single nucleotide polymorphism (SNP) by scanning the whole genome of certain species can lead to the understanding of mutation responsible for phenotypic diversity like disease susceptibility, morphology, and behavior.

\section{Genotyping-by-Sequencing (GBS)}

Genotyping-by-Sequencing or GBS is a highly multiplexed technique based on the Illumina sequencing method that was initially developed for plants [48, 49]. However, it is also applicable for population studies, molecular characterization, genetic improvement, and mapping complex traits in domestic animals [50]. It is quite efficient to identify large numbers of SNPs cost-effectively. It may be used as markers for breed characterization, genetic selection, genetic mapping, and genome-wide association studies (GWAS) of buffalo. Hence, the best buffalo species can be identified for further breeding based on SNPs identified across the whole genome.

\section{Epigenomic Screening}

As defined at Cold Spring Harbor meeting in 2008, epigenetics study stably heritable phenotype resulting from changes in a chromosome without alteration in the DNA sequence. This is the branch of genetics that deals with the effects of external or environmental factors on cellular and physiological phenotypic traits and-, in turn-, gene activity and expression. Other than the gene itself, some non-DNA changes like-DNA methylation, histone modification, non-coding RNA etc. often affect gene regulation and disease development. Efficient detection of such cellular events at the genetic level can reveal significant information about economically important traits of interest such as fertility, quality of milk and meat, immunity against certain diseases, etc. That's why epigenome-wide association of DNA modification with certain phenotypes can be our next important tool in domestic animal breeding strategies like Buffalo.

\section{MicroRNA's Expression Profiling}

MicroRNAs (miRNA) are small single-stranded noncoding RNA molecules found in plants, animals, and in some viruses [51]. They are notable for their function in gene silencing and post-transcriptional regulation of gene expression [52,53]. MicroRNAs play a significant role in host-pathogen interactions and disease pathogenesis in many animals, specifically buffaloes [54]. In a recent study conducted by Singh and colleagues, regulatory roles of miRNA were depicted in association with disease pathogenesis in water buffaloes [54]. They also found expression profiling of miRNA biomarkers helpful for disease diagnosis and treatment. Studies also unveiled the association of the miRNA expression profile of water buffalo and susceptibility of Johne's disease and Brucellosis. In another study, $\mathrm{Xu}$ and colleagues reported an alteration of immunity-related miRNA profile in murine macrophage in response to BCG infection [55]. They 
demonstrated that a particular miRNA (miR-142-3p) negatively regulated the production of pro-inflammatory mediators, namely NF-kB, TNF- $\alpha$, and IL-6, in the macrophages by down-regulating IRAK-1 protein expression.

MicroRNAs are also found effective in cell cycle regulation, growth, and progression in an in-silico study performed by Rani and colleagues [56]. The association of miRNA with these processes was assessed by analyzing the microRNA repertoire of buffalo milk exosomes during all lactation periods. In that study, analysis was performed using hub genes interaction, string, and Cytoscape network analysis; furthermore, they emphasized the functional role of microRNA in regulating the cellular processes and pathways using in vitro and in vivo models.

Huang and colleagues elucidated the characteristics of miRNA expression profile in buffalo's muscle and adipose tissues, which served as information for the identification of miRNAs with potential effects on intramuscular fat content (IMF) [57]. IMF is an important index that affects the tenderness and juiciness of the meat and its quality. They generated the first miRNA profile of longissimus dorsi muscle and back fat tissues in Chinese Buffalo, which might provide a basis for the further identification of miRNAs with a potential effect on IMF deposition in buffalo. Hence these small regulatory molecules can be our next target to track different cellular processes to diagnose different diseases or developmental stages in buffalo.

\section{Microarray Technology}

Microarray technology is a recently evolving genetic technique used to study the expression pattern of several genes at once. It involves several gene sequences placed on a glass slide called a gene chip which, when it comes in contact with target DNA or RNA, expresses a certain electrochemical signal. Hence, the gene expression level of several genes can be determined by analyzing the signal emitted from the gene chip [58]. This novel technique is now widely used on animals for large-scale gene expression studies involving SNP genotyping, polymorphisms, disease diagnosis, fertility assay etc. [59-64].

In a study by Yang and colleagues, microarray analysis had been used to differentiate and determine the interplay between natural hosts and parasites to identify the Schistosome (Schistosoma japonicum) target genes and their association with susceptibility to screen vaccine candidates [61]. Another study demonstrated transcriptional analysis of potential buffalo genes that are associated with buffalo oocyte maturation using the microarray technology [62]. Very recently, microarray technology had also been used to analyze the transcriptomic profile of buffalo spermatozoa that report the alteration of functionally relevant transcripts in low-fertile bull spermatozoa [63]. Thus, microarray technology can allow animal geneticists and breeders to select animals based on multiple traits and hopefully can revolutionize the buffalo production and breeding industry.

\section{Whole Genome Sequencing (WGS)}

Whole genome sequencing is a technique for a comprehensive study of the entire genome, which provides a high-resolution view of each base throughout the genome. It can reveal potential causative variants for gene expression and regulation mechanisms by generating large volumes of data quickly, which can also aid the assembly of novel genomes. A revolutionary advancement in wholegenome analysis has drastically improved domestic animals' genomic research and their application in reallife problem-solving. The High Throughput Next Generation Sequencing (HT-NGS) has significant contribution in whole-genome genotyping, analysis of epigenetic modification, detection of mutations, expression profiling of RNA to determine the economically important gene's expression, and quantifying miRNA expression level to track that trait after posttranslational modification. These genomic techniques can be applied in the case of buffalo for their breed upgradation and high yield to be benefited economically.

\section{Real-Time PCR}

A real-time polymerase chain reaction (real-time PCR), also termed as Quantitative polymerase chain reaction (Q-PCR), is a method that monitors the amount of targeted DNA molecule throughout the PCR reaction in real-time. This molecular biology-based technique is felicitous for investigating the expression of targeted genes responsible for important phenotypic traits by analyzing messenger RNA or mRNA as it can be directly correlated with the target gene expression. A study was conducted to validate the expression of 6 housekeeping genes, namely YWHAZ, SDHA, GAPDH, RPS15, RPS18, and RN18S1, using real-time PCR in buffalo oocytes and embryos of different stages [65]. This type of research can help interpret gene expression more accurately in these cells and understand the molecular events during development. 
Moreover, this quantitative technique is also commonly applied for diagnosis purposes, such as detecting infectious diseases and genetic abnormalities. In a study, real-time PCR was utilized to screen frozen semen of cattle and buffalo for the Bovine herpesvirus 1 (BoHV-1) infection, which showed high sensitivity $(100 \%)$ and specificity (90.04\%) [66]. In this way, realtime PCR can be applied in buffalo to investigate its genome by gene expression analysis and diagnose various diseases quickly and effectively.

\section{Fluorescence In Situ Hybridization (FISH)}

Fluorescence in situ hybridization (FISH) is a laboratory technique useful for locating a specific DNA sequence on a chromosome using a labeled probe. The fluorescent probe sequence specifically binds to its corresponding sequence on the chromosome. During the last twenty years, this technique has been used in the research of domestic animals to study chromosomal rearrangements, evolutionary chromosomes, gene mapping, and comparative mapping. However, FISH can be used in animals to localize genes of interest involved in fertility, milk and meat production, or other economically important traits. By using the FISH technique, three essential fecundity genes (TNF, STAT5A, and MTNR1A) were mapped on R-banded chromosomes of cattle, river buffalo sheep, and the goat for the first time, and extended the cytogenetic maps of this important species [67]. Tumor necrosis factor- $\alpha$ (TNF- $\alpha$ ) is important for male fertility $[68,69]$; signal transducer and activator of transcription 5A (STAT5A) is correlated to reproduction activity and milk production [70, 71]; melatonin receptor $1 \mathrm{~A}$ (MTNR1A) is essential for seasonality of reproduction $[72,73]$. Therefore, this technique may become an effective one to identify the targeted genes of interest or any mutations on buffalo's chromosomes to improve the genomic research of buffalo.

\section{Phylogenetic Analysis}

The phylogenetic analysis represents the evolutionary history or relationship among different species, organisms, or features of an organism (genes, proteins etc.). The phylogenetic analysis of DNA sequence reveals how an organism is related to another organism of different species. A significant, within and between populations, differences were seen in allelic variability of 21 microsatellite loci in 3 river buffalo and 8 swamp populations [74]. In another study, 20 bovine microsatellites among bovine species were studied, where Bubalus bubalis and Syncerus caffer were shown as the most divergent species in the Bos clade [75]. Characterization and phylogenetic analysis of the complete sequence of the D-loop region inside the mtDNA from buffaloes and cows was reported for the first time by Ramadan and colleagues [76]. Furthermore, the water buffalo interleukin-12 (IL-12) sequence revealed noticeable identity with IL-12 of bovine, while Indian water buffalo interleukin-18 (IL-18) showed $99 \%$ identity with cattle IL-18 in amino acid sequences [77].

Phylogenetic analysis based on cytochrome B gene of local endemic buffalo (Bubalus bubalis) found in central Indonesia had shown one major clade and two subclades [78]. It also revealed the close genetic relationship between the buffalo found in that part of Indonesia. Another analysis performed on the complete mitochondrial genome of Murrah buffalo revealed a close genetic relationship between the Bubalus bubalis found in India and Murrah buffalo [79]. Thus, phylogenetic analysis facilitates the identification of relationships within and between species at proteome and genome levels.

\section{CONCLUSION}

Buffalo is one of the key sources of animal protein worldwide, including in Bangladesh. Investigating buffalo genomics and proteomics, and molecular research has brought a bright possibility to develop upgraded breeds of animals vital for both milk and meat. This study emphasizes on buffalo's genomics and proteomics resources that would provide important information about buffalo breeds' up-gradation, conservation, milk production, and disease resistance. This study also focuses on the economic importance of buffalo in the context of Bangladesh. Lastly, buffalos are very much ignored in middle Asian countries. Proper consultation, promulgation, crossbreeding to get quality species, food conservation, and appropriate training are necessary to flourish this sector.

\section{REFERENCES}

[1] Habib MR, Haque MN, Rahman A, Aftabuzzaman M, Ali MM, Shahjahan M. Dairy buffalo production scenario in Bangladesh: a review. Asian J Med Biol Res 2017; 3: 30516. https://doi.org/10.3329/ajmbr.v3i3.34518

[2] Arefaine $\mathrm{H}$, Kashwa M. A review on strategies for sustainable buffalo milk production in Egypt. J Biol Agric Healthc 2015; 5: 63-7.

[3] Desta TT. Introduction of domestic Buffalo (Bubalus bubalis) into Ethiopia would be feasible. Renew Agric Food Syst 2012; 27: 305-13.

https://doi.org/10.1017/S1742170511000366 
[4] Chantalakhana C, Bunyavejchewin P. Buffaloes, and draught power. Outlook Agric 1994; 23: 91-5. https://doi.org/10.1177/003072709402300204

[5] Abd El-Salam MH, El-Shibiny S. A comprehensive review on the composition and properties of buffalo milk. Dairy Sci Technol 2011; 91: 663. https://doi.org/10.1007/s13594-011-0029-2

[6] Samad MA. A systematic review of research findings on buffalo health and production published during the last six decades in Bangladesh. J Vet Med OH Res 2020; 2: 1-62. https://doi.org/10.36111/jvmohr.2020.2(1).0016

[7] Dubey PC, Suman CL, Sanyal MK, Pandey HS, Saxena MM, Yadav PL. Factors affecting the composition of milk of buffaloes. Indian J Anim Sci 1997; 67.

[8] Naveena BM, Kiran M. Buffalo meat quality, composition, and processing characteristics: Contribution to the global economy and nutritional security. Anim Front 2014; 4: 18-24. https://doi.org/10.2527/af.2014-0029

[9] FAOSTAT. FAO statistics division. Rome, Italy: 2014

[10] Pasha TN, Hayat Z. Present situation and future perspective of buffalo production in Asia. J Anim Plant Sci 2012; 22: 250-6.

[11] Coroian A, Erler S, Matea CT, Mireșan V, Răducu C, Bele C. Seasonal changes of buffalo colostrum: physicochemical parameters, fatty acids, and cholesterol variation. Chem Cent J 2013; 7: 40.

https://doi.org/10.1186/1752-153X-7-40

[12] Statistics D of L. Annual report on livestock. Dhaka, Bangladesh, 2015.

[13] Faruque MO, Hasnath MA, Siddique NN. Present status of buffaloes and their productivity in Bangladesh. AsianAustralasian J Anim Sci 1990; 3: 287-92. https://doi.org/10.5713/ajas.1990.287

[14] Chakravarty AK. Strategies for genetic improvement of buffaloes through the production of quality male germplasm in SAARC countries. Semin. Pap. Present. "High Yielding Dairy Buffalo Breed Dev. SAARC Ctries., 2013.

[15] Nations $F$ and AO of the U. FAOSTAT Database, 2014

[16] Gonçalves EC, Silva A, Barbosa MSR, Schneider MPC. Isolation and characterization of microsatellite loci in Amazonian red-handed howlers Alouatta Beelzebub (Primates, Plathyrrini). Mol Ecol Notes 2004; 4: 406-8. https://doi.org/10.1111/j.1471-8286.2004.00667.x

[17] Uenoyama Y, Pheng V, Tsukamura H, Maeda K. The roles of kisspeptin revisited: inside and outside the hypothalamus. J Reprod Dev 2016.

https://doi.org/10.1262/jrd.2016-083

[18] Scott CJ, Rose JL, Gunn AJ, McGrath BM. Kisspeptin and the regulation of the reproductive axis in domestic animals. $J$ Endocrinol 2019; 240: R1-16.

https://doi.org/10.1530/JOE-18-0485

[19] Bhardwaj S, Kumar P, Jerome A, Ravesh S, Patil C, Singh P. Serum kisspeptin: New possible biomarker for sexual behaviour and sperm concentration in buffalo bulls. Reprod Domest Anim 2020; 55: 1190-201.

https://doi.org/10.1111/rda.13761

[20] Sikka P, Nath A, Paul SS, Andonissamy J, Mishra DC, Rao AR. Inferring relationship of blood metabolic changes and average daily gain with feed conversion efficiency in murrah heifers: machine learning approach. Front Vet Sci 2020; 7. https://doi.org/10.3389/fvets.2020.00518

[21] Singh HP, Jain RK, Tiwari D, Mehta MK, Mudgal V. Strategic supplementation of antioxidant micronutrients in periparturient murrah buffaloes helps augment the udder health and milk production. Biol Trace Elem Res 2020; 1-9. https://doi.org/10.1007/s12011-020-02319-0

[22] Saini M, Sheoran S, Vijayalakshmy K, Rajendran R, Kumar $D$, Kumar P. Semen parameters and fertility potency of a cloned water buffalo (Bubalus bubalis) bull produced from a semen-derived epithelial cell. PLoS One 2020; 15: e0237766.

https://doi.org/10.1371/journal.pone.0237766

[23] Jan MH, Kumar H, Kumar S, Sharma RK, Gupta A, Mehrara $\mathrm{KL}$. Effect of progesterone administration during the growing phase of first dominant follicle on follicular wave pattern in buffalo heifers. Trop Anim Health Prod 2020; 52: 1395-402. https://doi.org/10.1007/s11250-019-02143-2

[24] Mishra DC, Sikka P, Yadav S, Bhati J, Paul SS, Jerome A Identification and characterization of trait-specific SNPs using ddRAD sequencing in water buffalo. Genomics 2020. https://doi.org/10.1016/j.ygeno.2020.04.012

[25] Selokar NL, Dua S, Kumar D, Sharma B, Saini M. Application of nanotechnology in agricultural farm animals. Biog. NanoParticles their Use Agro-ecosystems, Springer 2020; p. 1-8. https://doi.org/10.1007/978-981-15-2985-6 1

[26] Buffalo farm of Luvas declared best center of the country. Dainik Jagran. 2017 Jul. Available from: https://www.jagran.com/haryana/hisar-16429094.html

[27] Khan MS, Ahmad N, Khan MA. Genetic resources and diversity in dairy buffaloes of Pakistan. Pak Vet J 2007; 27: 201.

[28] Osmani A, Robertson ID, Habib I, Aslami AA. History and epidemiology of foot-and-mouth disease in Afghanistan: a retrospective study. BMC Vet Res 2019; 15: 340. https://doi.org/10.1186/s12917-019-2119-y

[29] Lau SKP, Tsang AKL, Ahmed SS, Alam MM, Ahmed Z Wong P-C. First genome sequences of buffalo coronavirus from water buffaloes in Bangladesh. New Microbes New Infect 2016; 11: 54-6. https://doi.org/10.1016/j.nmni.2016.02.011

[30] Mintoo AA, Zhang H, Chen C, Moniruzzaman M, Deng T, Anam M, . Draft genome of the river water buffalo. Ecol Evol 2019; 9: 3378-88.

https://doi.org/10.1002/ece3.4965

[31] Dutta P, Talenti A, Young R, Jayaraman S, Callaby $R$, Jadhav SK. Whole genome analysis of water buffalo and global cattle breeds highlights convergent signatures of domestication. Nat Commun 2020; 11: 1-13. https://doi.org/10.1038/s41467-020-18550-1

[32] Yue X-P, Li R, Xie W-M, Xu P, Chang T-C, Liu L. Phylogeography and domestication of Chinese swamp buffalo. PLoS One 2013; 8: e56552. https://doi.org/10.1371/journal.pone.0056552

[33] Yang WC, Tang KQ, Mei J, Zeng WB, Yang LG. Genetic diversity analysis of an indigenous Chinese buffalo breed and hybrids based on microsatellite data. Genet Mol Res 2011; 10: 3421-6. https://doi.org/10.4238/2011.December.5.1

[34] Deng T, Pang C, Lu X, Zhu P, Duan A, Tan Z. De novo transcriptome assembly of the Chinese swamp buffalo by RNA sequencing and SSR marker discovery. PLoS One 2016; 11: e0147132.

\section{https://doi.org/10.1371/journal.pone.0147132}

[35] Kumar S, Nagarajan M, Sandhu JS, Kumar N, Behl V Nishanth G. Mitochondrial DNA analyses of Indian water buffalo support a distinct genetic origin of river and swamp buffalo. Anim Genet 2007; 38: 227-32. https://doi.org/10.1111/j.1365-2052.2007.01602.x

[36] Moaeen-Ud-Din M. Buffalo genome research-a review. Anim Sci Pap Reports 2014; 32: 187-99.

[37] Albuquerque MSM, Do Egito AA, Felipe Marques JR, Ciampi AY, Mariante ADS, Ribeiro Castro ST. Genetic variability in buffaloes estimated by RAPD markers. Brazilian Agric Res 2006; 41: 623-8.

\section{https://doi.org/10.1590/S0100-204X2006000400011}

[38] Meignanalakshmi S, Nainar AM. PCR-RFLP analysis of betalactoglobulin gene in Murrah buffaloes. Tamilnadu $\mathrm{J}$ Vet Anim Sci 2009; 5: 194-7. 
[39] Abdel-Rahman SM. Evidences reveal that cattle and Buffalo evolutionary derived from the same ancestor based on cytogenetic and molecular markers. Biotechnol Anim Husb 2006; 22: 1-9.

https://doi.org/10.2298/BAH0604001A

[40] Nagarajan M, Kumar N, Nishanth G, Haribaskar R, Paranthaman K, Gupta J. Microsatellite markers of water buffalo, Bubalus bubalis-development, characterisation and linkage disequilibrium studies. BMC Genet 2009; 10: 1-7. https://doi.org/10.1186/1471-2156-10-68

[41] Moolmuanga B, Srapheta S, Na-Chiangmai A, Smitha DR, Panyima S, Triwitayakorna K. Application of AFLP technique to the study of calving interval trait of Thai swamp buffalo (Bubalus bubalis). ScienceAsia 2007; 33: 161-4. https://doi.org/10.2306/scienceasia1513-1874.2007.33.161

[42] Kiran M, Naveena BM, Reddy KS, Shahikumar M, Reddy VR, Kulkarni V V, . Understanding tenderness variability and ageing changes in buffalo meat: biochemical, ultrastructural and proteome characterization. Animal 2016; 10: 1007-15. https://doi.org/10.1017/S1751731115002931

[43] Das AK, Sharma D, Kumar N. Buffalo genetic resources in India and their conservation. Buffalo Bull 2008; 27: 265-8.

[44] Ahmed SS, Abd el Aziz KB, Hassan NA, Mabrouk DM. Genetic polymorphism of some genes related to reproductive traits and their association with calving interval in Egyptian Buffalo. GQG 2011; 3: 13-9.

[45] Huang Y, Fu Q, Yang L, Guan J, Pan H, Chen F. Differences between high-and low-motility buffalo sperm identified by comparative proteomics. Reprod Domest Anim 2015; 50: 443-51.

https://doi.org/10.1111/rda.12511

[46] Bush WS, Moore JH. Genome-wide association studies. PLoS Comput Biol 2012; 8: e1002822. https://doi.org/10.1371/journal.pcbi.1002822

[47] Koopaei HK, Koshkoiyeh AE. Application of genomic technologies to the improvement of meat quality in farm animals. Biotechnol Mol Biol Rev 2011; 6: 126-32.

[48] Davey JW, Hohenlohe PA, Etter PD, Boone JQ, Catchen JM, Blaxter ML. Genome-wide genetic marker discovery and genotyping using next-generation sequencing. Nat Rev Genet 2011; 12: 499-510.

https://doi.org/10.1038/nrg3012

[49] Gore MA, Chia J-M, Elshire RJ, Sun Q, Ersoz ES, Hurwitz $\mathrm{BL}$. A first-generation haplotype map of maize. Science (80- ) 2009; 326: 1115-7.

https://doi.org/10.1126/science. 1177837

[50] De Donato M, Peters SO, Mitchell SE, Hussain T, Imumorin IG. Genotyping-by-sequencing (GBS): a novel, efficient, and cost-effective genotyping method for cattle using nextgeneration sequencing. PLoS One 2013; 8: e62137. https://doi.org/10.1371/journal.pone.0062137

[51] Bartel DP. Metazoan MicroRNAs. Cell 2018; 173: 20-51. https://doi.org/10.1016/j.cell.2018.03.006

[52] Bartel DP. MicroRNAs: target recognition and regulatory functions. Cell 2009; 136: 215-33. https://doi.org/10.1016/j.cell.2009.01.002

[53] Fabian MR, Sonenberg N, Filipowicz W. Regulation of mRNA translation and stability by microRNAs. Annu Rev Biochem 2010; 79: 351-79.

https://doi.org/10.1146/annurev-biochem-060308-103103

[54] Singh J, Dhanoa JK, Choudhary RK, Singh A, Sethi RS, Kaur S. MicroRNA expression profiling in PBMCs of Indian water buffalo (Bubalus bubalis) infected with Brucella and Johne's disease. ExRNA 2020; 2 : 8. https://doi.org/10.1186/s41544-020-00049-y

[55] Xu G, Zhang Z, Wei J, Zhang Y, Zhang Y, Guo L. MicroR142-3p down-regulates IRAK-1 in response to Mycobac- terium Bovis BCG infection in macrophages. Tuberculosis 2013; 93: 606-11.

https://doi.org/10.1016/j.tube.2013.08.006

[56] Rani P, Onteru S, Bioscience DS-F, 2020 undefined. Genome-wide profiling and analysis of microRNA expression in buffalo milk exosomes. Elsevier n.d. https://doi.org/10.1016/j.fbio.2020.100769

[57] Huang J, Wang S, Feng X, Liu X, Zhao J, Zheng Q. miRNA transcriptome comparison between muscle and adipose tissues indicates potential miRNAs associated with intramuscular fat in Chinese swamp buffalo. Genome 2019; 62: 729-38.

https://doi.org/10.1139/gen-2018-0178

[58] Taub FE, Deleo JM, Thompson EB. Sequential Comparative Hybridizations Analyzed by Computerized Image Processing Can Identify and Quantitate Regulated RNAs. DNA 1983; 2: 309-27. https://doi.org/10.1089/dna.1983.2.309

[59] Beena V, Pawaiya R, Gururaj K, Shivasharanappa S Karikalan M. Application of Microarray in Animal Disease Pathogenesis and Diagnosis. J Vet Sci Technol 2016; 07. https://doi.org/10.4172/2157-7579.1000402

[60] Patil M, Bhong C. Veterinary Diagnostics and DNA Microarray Technology. Int J Livest Res 2015; 5: 1. https://doi.org/10.5455/ijlr.20150330032234

[61] Yang J, Hong Y, Yuan C, Fu Z, Shi Y, Zhang M. Microarray Analysis of Gene Expression Profiles of Schistosoma japonicum Derived from Less-Susceptible Host Water Buffalo and Susceptible Host Goat. PLoS One 2013; 8. https://doi.org/10.1371/journal.pone.0070367

[62] Kandil OM, Ghanem N, Abdoon ASS, Hölker M, Phatsara C, Schellander K. Transcriptional analysis of buffalo (Bubalus bubalis) oocytes during in vitro maturation using bovine cDNA microarray. Reprod Domest Anim 2010; 45: 63-74. https://doi.org/10.1111/j.1439-0531.2008.01238.x

[63] Paul N, Kumaresan A, Das Gupta M, Nag P, Guvvala PR, Kuntareddi C. Transcriptomic Profiling of Buffalo Spermatozoa Reveals Dysregulation of Functionally Relevant mRNAs in Low-Fertile Bulls. Front Vet Sci 2021; 7: 1-15.

https://doi.org/10.3389/fvets.2020.609518

[64] El-Ashker M, Gwida M, Monecke S, Ehricht R, Elsayed M, ElGohary F. Microarray-based detection of resistance genes in coagulase-negative staphylococci isolated from cattle and Buffalo with mastitis in Egypt. Trop Anim Health Prod 2020; 52: 3855-62. https://doi.org/10.1007/s11250-020-02424-1

[65] Kumar P, Yadav P, Verma A, Singh D, De S, Datta TK. Identification of stable reference genes for gene expression studies using quantitative real-time PCR in buffalo oocytes and embryos. Reprod Domest Anim 2012; 47: e88-91. https://doi.org/10.1111/j.1439-0531.2012.01998.x

[66] Rana SK, Kota S, Samayam PNR, Rajan S, Srinivasan VA. Use of real-time polymerase chain reaction to detect bovine herpesvirus 1 in frozen cattle and buffalo semen in India. Vet Ital 2011; 47: 313-22.

[67] lannuzzi A, Perucatti A, Pauciullo A, Genualdo V, De Lorenzi $L$, Parma $P$. Fluorescent in situ hybridization mapping of three fecundity genes on cattle, river buffalo, sheep, and goat. Caryologia 2015; 68: 9-12.

https://doi.org/10.1080/00087114.2014.996038

[68] Eggert-Kruse W, Kiefer I, Beck C, Demirakca T, Strowitzki T. Role for tumor necrosis factor a (TNF-a) and interleukin 1-b (IL-1b) determination in seminal plasma during infertility investigation. Fertil Steril 2007; 87: 810-23.

https://doi.org/10.1016/j.fertnstert.2006.08.103

[69] Koçak I, Yenisey C, Dündar M, Okyay P, Serter M. Relationship between seminal plasma interleukin- 6 and 
tumor necrosis factor a levels with semen parameters in fertile and infertile men. Urol Res 2002; 30: 263-7. https://doi.org/10.1007/s00240-002-0269-y

[70] Yang J, Kennelly JJ, Baracos VE. Physiological levels of Stat5 DNA binding activity and protein in bovine mammary gland. J Anim Sci 2000; 78: 3126-34.

https://doi.org/10.2527/2000.78123126x

[71] Homer EM, Derecka K, Webb R, Garnsworthy PC. Mutations in genes involved in oestrous cycle associated expression of oestrus. Anim Reprod Sci 2013; 142: 106-12. https://doi.org/10.1016/j.anireprosci.2013.09.018

[72] Chu MX, He YQ, Cheng DX, Ye SC, Fang L, Wang JY. Association between expression of reproductive seasonality and alleles of melatonin receptor $1 \mathrm{~A}$ in goats. Anim Reprod Sci 2007; 101: 276-84. https://doi.org/10.1016/j.anireprosci.2006.09.012

[73] Luridiana S, Mura MC, Pazzola M, Paludo M, Cosso G, Dettori ML. Association between melatonin receptor 1A (MTNR1A) gene polymorphism and the reproductive performance of Mediterranean Italian buffaloes. Reprod Fertil Dev 2012; 24: 983-7.

https://doi.org/10.1071/RD11297

[74] Barker JSF, Moore SS, Hetzel DJS, Evans D, Byrne K, Tan SG. Genetic diversity of Asian water buffalo (Bubalus bubalis): microsatellite variation and a comparison with protein-coding loci. Anim Genet 1997; 28: 103-15. https://doi.org/10.1111/j.1365-2052.1997.00085.x
[75] Ritz LR, Glowatzki-Mullis M, MacHugh DE, Gaillard C. Phylogenetic analysis of the tribe Bovini using microsatellites. Anim Genet 2000; 31: 178-85. https://doi.org/10.1046/j.1365-2052.2000.00621.x

[76] Ramadan HAl, El-Hefnawi MM. Phylogenetic analysis and comparison between cow and Buffalo (including Egyptian buffaloes) mitochondrial displacement-loop regions: FullLength Research Paper. DNA Seq 2008; 19: 401-10. https://doi.org/10.1080/19401730802351004

[77] Kole C, Cockett NE, Kole C. Genome Mapping and Genomics in Domestic Animals. Springer, 2009. https://doi.org/10.1007/978-3-540-73835-0

[78] Amin M, Suarsini E, Azmi I, Gofur A. Phylogenetic analysis of local endemic Buffalo (Bubalus bubalis) based on cytochrome B gene in central Indonesia. J Teknol 2016; 78: 393-7.

https://doi.org/10.11113/jt.v78.8343

[79] Lin Q, Li M-W, Wang Y-Z, Qiu H-J. Determination and phylogenetic analysis of the complete mitochondrial genome of Bubalus bubalis Linnaeus, 1758 breed Murrah (Artiodactyla: Bovidae). Mitochondrial DNA Part B 2020; 5: 432-3.

https://doi.org/10.1080/23802359.2019.1704181

https://doi.org/10.6000/1927-520X.2021.10.04

(C) 2021 Sikdar et al.; Licensee Lifescience Global.

This is an open access article licensed under the terms of the Creative Commons Attribution Non-Commercial License (http://creativecommons.org/licenses/by-nc/3.0/) which permits unrestricted, non-commercial use, distribution and reproduction in any medium, provided the work is properly cited. 